\title{
Effects of egg weight and length of storage on hatchability and subsequent growth performance of quail
}

\author{
M. Petek ${ }^{\#}$, H. Baspinar and M. Ogan \\ University of Uludag, Faculty of Veterinary Medicine, Department of Zootechnics, 16059 Bursa, Turkey
}

\begin{abstract}
This study was to investigate the effects of hatching egg weight and length of storage period on hatchability and subsequent growth performance of quail. A total of 2304 eggs was collected from a quail flock, aged 17 weeks. The eggs were divided into four groups on the basis of storage periods of $1,3,5$ or 7 days. Prior to egg storage, the eggs in each group were classified according to egg weight, as small: $<10.51$ g; medium: 10.51-11.50 g; large: 11.51-12.50 g; and jumbo: $>12.51 \mathrm{~g}$. Hatchability of total and of fertile eggs increased significantly with an increase in egg weight but was not affected by duration of egg storage. There were no significant effects of egg storage period on body weight and feed conversion ratio of the progeny at six weeks of age. The average body weight of the quail produced from heavier eggs (large and jumbo) was significantly higher than those from the smaller eggs. It is recommended that the storage period should be no longer than 3 days. Eggs heavier than $11.50 \mathrm{~g}$ were found to be the most suitable for successful hatching and subsequent growth performance.
\end{abstract}

Keywords: Quail, egg weight, storage period, hatchability, growth performance

${ }^{\#}$ Corresponding author. E-mail: petek@uludag.edu.tr

\section{Introduction}

Long egg storage periods affect the $\mathrm{pH}$ of the albumen due to loss of carbon dioxide (Dawes, 1975), which is important in maintaining embryonic viability, and result in decreased hatchability (Kirk et al., 1980; Deeming, 2000; Heier \& Jarp 2001). Eggs incubated on the day of lay produced heavier chicks than eggs stored for a number of days (Reis et al., 1997). Small eggs also produced smaller chickens with a lower performance than chickens hatched from larger eggs (Among et al., 1984; Farooq et al., 2001). Although numerous studies have shown that there is strong positive correlation between pre-incubation egg weight, length of storage periods, hatchlings weight and growth performance of different species of poultry (Ayorinde et al., 1994; Danczak \& Majewska, 1999; McLoughlin \& Gous, 1999; Farooq et al., 2001; Heier \& Jarp, 2001; Nahm, 2001), the effects of length of egg storage and hatching egg weight on the hatchability and subsequent growth performance of quail have not been fully investigated. Therefore, the objective of the present study was to examine the effect of egg weight and length of storage on hatchability and subsequent growth performance of quail and to determine the optimal pre-incubation egg storage period and optimal weight of eggs destined for hatching.

\section{Materials and Methods}

This research was conducted at the Livestock Research Centre of the Faculty of Veterinary Medicine in Bursa, Turkey. A total of 2304 eggs was collected from a 17 week old quail flock of the Pharaoh strain (Coturnix coturnix Pharaoh), bred at the centre. The eggs were allocated to four groups, to be stored for 1, 3 , 5 or 7 days. Prior to storage, the eggs were divided into size groups according to egg weights, viz. small: $<10.51 \mathrm{~g}$; medium: 10.51-11.50 g; large: $11.51-12.50 \mathrm{~g}$; and jumbo: $>12.51 \mathrm{~g}$. Eggs were stored at $18{ }^{\circ} \mathrm{C}$ and $75 \%$ relative humidity, and turned twice a day. One hundred and forty-four eggs from each group were incubated in a commercial hatchery. Forty-eight eggs constituted a replicate in each group.

The setter was operated at $37.5 \pm 0.5^{\circ} \mathrm{C}$ dry bulb temperature and $29.0 \pm 0.5^{\circ} \mathrm{C}$ wet bulb temperature. The hatcher was operated at $37.0 \pm 0.5^{\circ} \mathrm{C}$ dry bulb temperature and $31.0 \pm 0.5{ }^{\circ} \mathrm{C}$ wet bulb temperature. The eggs in the incubator were turned 15 times per day. Trays representing all egg weights and storage period treatment groups were distributed in the setter and hatcher to minimize possible machine position effects that could be due to differences in air flow rate.

The hatcher was opened at 396, 400, 404, and $408 \mathrm{~h}$ of incubation and all the chicks that fully emerged from their eggs were removed, counted and placed again in the hatcher. All chicks were removed at 
$418 \mathrm{~h}$ post-incubation and weighed individually to the nearest $0.05 \mathrm{~g}$. From the data, hatching time (number of chicks hatched per number of all eggs set per control x 100) was calculated. All unhatched eggs in each treatment were opened and examined macroscopically to determine percentage fertility, percentage hatchability of fertile and total eggs. Hatchability of fertile or total eggs was calculated as the number of chicks hatched per fertile or total eggs set. The fertility results were reported as "apparent fertility" and presented in concert with hatchability of fertile and total eggs to provide unbiased data.

The newly hatched chicks from all groups were reared under the same growing conditions in battery cages in an open-sided house with mechanical ventilation. Chicks belonging to the same group were randomly allocated into three replicates at hatch. After being separated at three weeks of age according to sex on the basis of thoracic feather colour and through cloaca inspection by an experienced person, 25 female and 25 male quails in each group were transferred from the brooding cages to growing cages. These chicks were brooded and reared at $28{ }^{\circ} \mathrm{C}$ for the first week, $27{ }^{\circ} \mathrm{C}$ during the second week, $24{ }^{\circ} \mathrm{C}$ during the third week and $18-21{ }^{\circ} \mathrm{C}$ from the fourth week to 6 week of age. A 24-h constant lighting regimen was used throughout the experiment. Standard production practices and quail growth ration produced at the Research Centre were used during the treatment. All birds had ad lib. access to feed and water. The diet was formulated according to NRC (1994) guidelines and the nutrient content of the diet is presented in Table 1. Chemical analyses of the diet were done, using the international procedures of AOAC (1990) and are presented in Table1.

Table 1 Ingredient and chemical composition of the experimental diet

\begin{tabular}{lc|lc}
\hline Ingredients & $\begin{array}{c}\text { Dry matter } \\
\mathbf{\%}\end{array}$ & Chemical composition & $\begin{array}{c}\text { Dry matter } \\
\mathrm{mg} / \mathrm{kg}\end{array}$ \\
\hline Maize & 54.88 & Crude protein & 220 \\
Soyabean meal (48\%) & 24.00 & Metabolisable energy (MJ/kg) & 12.92 \\
Full-fat soyabean & 7.16 & Crude fibre & 28.4 \\
Fish meal & 6.00 & Crude fat & 89.0 \\
Sunflower meal & 0.50 & Ash & 41.4 \\
Vegetable oil & 4.86 & Calcium & 10.0 \\
Dicalcium phosphate & 1.30 & Phosphorus & 7.6 \\
Sodium chloride & 0.36 & Lysine & 11.4 \\
Limestone, ground & 0.55 & Methionine & 5.0 \\
DL-methionine & 0.17 & Sodium & 2.0 \\
Oxiform Dry $^{1}$ & 0.01 & & \\
Vitamin and trace mineral premix & & \\
Coccidiostat & & &
\end{tabular}

${ }^{1}$ Oxiform Dry-I: antioxidant (Farmavet İlaç Sanayii, Istanbul, Turkey)

${ }^{2}$ Vitamin and trace mineral premix provided the followings per $2.5 \mathrm{~kg}$ of diet:

Vitamin A - $700000 \mathrm{IU}$; vitamin $\mathrm{D}_{3}-300000 \mathrm{IU}$; vitamin E - $5000 \mathrm{mg}$; vitamin $\mathrm{B}_{1}$ - $8000 \mathrm{mg}$; vitamin $\mathrm{K}_{3}$ - $4000 \mathrm{mg}$; vitamin $\mathrm{B}_{2}-1600 \mathrm{mg}$; vitamin $\mathrm{B}_{6}-1200 \mathrm{mg}$; vitamin $\mathrm{B}_{12}$ - $12 \mathrm{mg}$; pantotenic acid - $4000 \mathrm{mg}$; niasin - $6000 \mathrm{mg}$; folic acid - 400 mg; biotin - 120 mg; colin chloride - 400000 mg; Cu - 2000 mg; I - 120 mg; Co - 100 mg; Se - 80 mg; Mn 24000 mg; Fe - 48000 mg; Zn - 6000 mg; calcium D- Pantotenat - 800 mg; BHT - 10000 mg; niacin - 2000 mg

${ }^{3}$ Robifarm 33 Dry: anticoccidial (Farmavet İlaç Sanayii, Istanbul, Turkey)

Individual body weights of the quail at hatching and at 42 days of age were measured to determine chick weight and growth. The feed conversion ratio (kilograms of feed intake per kilogram of body weight gain) and mortality were calculated for the 42 days of growth period. Mortality rate was determined by dividing the number of dead by the number of quail at the beginning of growing period in a group. The European Efficiency Factor was calculated according to the method described by Nilipour (1998) at the end of the growth period. 
The results for hatching time, apparent fertility, hatchability of fertile and total eggs, body weight at hatch and 42 days of age were analysed by two-way analysis of variance. When differences among the groups were significant, means were separated, using the Tukey test. Arc sine transformation was performed on hatching time, apparent fertility, hatchability of fertile and total eggs data prior to analyses. For feed conversion, the Kruskal-Wallis non-parametric ANOVA and Dunn's multiple comparisons tests were applied to indicate differences among the main groups. Mortality rates among the groups were analysed by the Chi-Square test procedure (Snedecor \& Cochran, 1989). All analyses were performed using SPSS ${ }^{\circledR}$ computer software 10.00 (SPSS Inc. Chicago, USA 1999). Setting egg weight and length of egg storage period were the main effects.

\section{Results and Discussion}

Table 2 The effect of hatching egg weight and length of egg storage on hatching time, apparent fertility, hatchability of fertile and total eggs ${ }^{1}$

\begin{tabular}{|c|c|c|c|c|c|c|c|c|c|}
\hline \multirow{2}{*}{$\begin{array}{c}\begin{array}{c}\text { Storage } \\
\text { Period }\end{array} \\
\text { days } \\
\end{array}$} & \multirow[t]{2}{*}{$\begin{array}{c}\text { Hatching }^{\S} \\
\text { egg size }\end{array}$} & \multirow[t]{2}{*}{$\begin{array}{c}\text { Number } \\
\text { of eggs }\end{array}$} & \multicolumn{4}{|c|}{$\begin{array}{l}\text { Hatching time distribution (h) } \\
\text { Hatchability at: }\end{array}$} & \multicolumn{2}{|c|}{$\begin{array}{c}\text { Hatchability } \\
\%\end{array}$} & \multirow[t]{2}{*}{$\begin{array}{c}\text { Apparent } \\
\text { fertility }\end{array}$} \\
\hline & & & $396 * *$ & $400 *$ & $404 * *$ & $408^{* *}$ & fertile eggs & total eggs & \\
\hline \multicolumn{10}{|c|}{ Interactive Effects } \\
\hline 1 & Small & 144 & 59.81 & 68.91 & 76.78 & 80.63 & 92.65 & 81.82 & 88.31 \\
\hline 1 & Medium & 144 & 52.27 & 72.18 & 81.58 & 82.60 & 96.43 & 84.38 & 87.50 \\
\hline 1 & Large & 144 & 47.95 & 63.52 & 81.28 & 84.35 & 97.67 & 87.50 & 89.58 \\
\hline 1 & Jumbo & 144 & 33.32 & 59.39 & 86.44 & 86.44 & 96.63 & 89.58 & 92.71 \\
\hline 3 & Small & 144 & 1.56 & 5.98 & 71.61 & 82.29 & 93.55 & 86.57 & 92.54 \\
\hline 3 & Medium & 144 & 5.18 & 35.57 & 85.78 & 88.87 & 95.60 & 90.63 & 94.79 \\
\hline 3 & Large & 144 & 24.88 & 47.73 & 88.88 & 88.88 & 92.13 & 85.42 & 92.71 \\
\hline 3 & Jumbo & 144 & 20.92 & 24.01 & 80.51 & 84.69 & 97.75 & 90.63 & 92.71 \\
\hline 5 & Small & 144 & 1.51 & 1.51 & 3.10 & 8.71 & 88.68 & 72.31 & 81.54 \\
\hline 5 & Medium & 144 & 0 & 0 & 46.76 & 82.87 & 95.51 & 90.43 & 94.68 \\
\hline 5 & Large & 144 & 0 & 0 & 72.91 & 81.25 & 94.14 & 83.33 & 88.54 \\
\hline 5 & Jumbo & 144 & 0 & 0 & 53.75 & 84.29 & 96.59 & 89.47 & 92.63 \\
\hline 7 & Small & 144 & 0 & 0 & 0 & 6.78 & 91.69 & 77.03 & 83.78 \\
\hline 7 & Medium & 144 & 0 & 0 & 11.58 & 67.27 & 93.67 & 77.89 & 83.16 \\
\hline 7 & Large & 144 & 0 & 0 & 24.16 & 86.07 & 98.82 & 88.42 & 89.47 \\
\hline 7 & Jumbo & 144 & 0 & 0 & 1.03 & 19.11 & 95.29 & 86.17 & 90.43 \\
\hline \multicolumn{10}{|l|}{ Main Effects } \\
\hline 1 & & 576 & 47.61 & 65.68 & $81.55^{\mathrm{a}}$ & $83.47^{\mathrm{a}}$ & 95.84 & 85.82 & $89.52^{\mathrm{ab}}$ \\
\hline 3 & & 576 & 13.81 & 29.60 & $81.21^{\mathrm{a}}$ & $85.43^{\mathrm{a}}$ & 94.75 & 88.31 & $92.93^{\mathrm{a}}$ \\
\hline 5 & & 576 & 0.27 & 0.27 & $47.15^{b}$ & $68.32^{b}$ & 93.73 & 83.88 & $89.34^{\mathrm{ab}}$ \\
\hline 7 & & 576 & 0.00 & 0.00 & $9.72^{c}$ & $46.98^{\mathrm{c}}$ & 94.93 & 82.37 & $86.71^{\mathrm{b}}$ \\
\hline Significance & & & $*$ & $*$ & $*$ & $*$ & n.s & n.s & $*$ \\
\hline & Small & 576 & $16.93^{\mathrm{a}}$ & $20.11^{b}$ & $38.16^{\mathrm{c}}$ & $45.24^{\mathrm{d}}$ & $91.70^{\mathrm{b}}$ & $79.43^{b}$ & 86.54 \\
\hline & Medium & 576 & $14.43^{b}$ & $27.07^{\mathrm{a}}$ & $56.46^{\mathrm{b}}$ & $80.43^{b}$ & $95.30^{\mathrm{a}}$ & $85.83^{\mathrm{a}}$ & 90.03 \\
\hline & Large & 576 & $17.99^{a}$ & $27.38^{\mathrm{a}}$ & $66.04^{\mathrm{a}}$ & $84.30^{\mathrm{a}}$ & $95.69^{\mathrm{a}}$ & $86.16^{\mathrm{a}}$ & 90.05 \\
\hline & Jumbo & 576 & $13.71^{\mathrm{b}}$ & $20.01^{b}$ & $55.66^{\mathrm{b}}$ & $68.8^{c}$ & $96.56^{\mathrm{a}}$ & $88.96^{\mathrm{a}}$ & 92.12 \\
\hline & Significance & & $*$ & $*$ & * & $*$ & $*$ & * & $\mathrm{n} . \mathrm{s}$ \\
\hline
\end{tabular}

\footnotetext{
${ }^{\S}$ Small: <10.51 g; medium: 10.51-11.50 g; large: 11.51-12.50 g; jumbo: >12.51 g.

* Incubation time $(\mathrm{h})$; ${ }^{* *}$ Hatchability of total eggs from the beginning of incubation to control point

${ }^{\mathrm{a}-\mathrm{c}}$ within columns, within effects, values with different superscripts differ significantly at $* \mathrm{P}<0.05$

1 Three replicate trays for interaction means
} 
Table 3 The effect of hatching egg weight and length of egg storage on body weight at hatch and $42 \mathrm{~d}$ of age (mean \pm s.e.m.), FCR, mortality and European Efficiency Factor in quail hatched from the eggs

\begin{tabular}{|c|c|c|c|c|c|c|c|c|}
\hline \multirow{2}{*}{$\begin{array}{c}\text { Storage } \\
\text { period } \\
\text { days }\end{array}$} & \multirow[t]{2}{*}{$\begin{array}{l}\mathrm{Egg}^{\S} \\
\text { size }\end{array}$} & \multicolumn{2}{|c|}{$\mathbf{n}$} & \multicolumn{2}{|c|}{$\begin{array}{c}\text { Body weight } \\
(\mathrm{g}) \\
\end{array}$} & \multirow[t]{2}{*}{ FCR } & \multirow[t]{2}{*}{$\begin{array}{l}\text { Mortality } \\
(\%)\end{array}$} & \multirow{2}{*}{$\begin{array}{c}\text { European } \\
\text { Efficiency } \\
\text { Factor }\end{array}$} \\
\hline & & 0-3 wk & 4-6 wk & At hatch & $42 \mathrm{~d}$ of age & & & \\
\hline \multicolumn{9}{|c|}{ Interactive effects } \\
\hline 1 & Small & 118 & 50 & $6.82 \pm 0.08$ & $185.1 \pm 10.0$ & 2.91 & 9.52 & 13.70 \\
\hline 1 & Medium & 122 & 50 & $7.84 \pm 0.06$ & $183.1 \pm 12.3$ & 2.95 & 3.70 & 14.23 \\
\hline 1 & Large & 126 & 50 & $8.50 \pm 0.06$ & $190.9 \pm 13.1$ & 2.80 & 2.38 & 15.85 \\
\hline 1 & Jumbo & 129 & 50 & $9.45 \pm 0.10$ & $196.0 \pm 11.2$ & 2.92 & 2.32 & 15.61 \\
\hline 3 & Small & 125 & 50 & $6.85 \pm 0.08$ & $186.1 \pm 13.1$ & 2.95 & 10.34 & 13.47 \\
\hline 3 & Medium & 131 & 50 & $7.86 \pm 0.04$ & $179.5 \pm 12.5$ & 3.05 & 5.74 & 13.21 \\
\hline 3 & Large & 123 & 50 & $8.59 \pm 0.05$ & $192.2 \pm 11.7$ & 2.67 & 2.43 & 16.72 \\
\hline 3 & Jumbo & 131 & 50 & $9.60 \pm 0.10$ & $187.0 \pm 12.1$ & 3.04 & 1.14 & 14.48 \\
\hline 5 & Small & 104 & 50 & $6.81 \pm 0.09$ & $176.4 \pm 11.7$ & 3.23 & 6.38 & 12.19 \\
\hline 5 & Medium & 130 & 50 & $7.94 \pm 0.06$ & $182.0 \pm 12.4$ & 3.00 & 1.17 & 14.28 \\
\hline 5 & Large & 120 & 50 & $8.60 \pm 0.07$ & $187.3 \pm 12.0$ & 3.19 & 6.25 & 13.11 \\
\hline 5 & Jumbo & 129 & 50 & $9.47 \pm 0.09$ & $191.5 \pm 13.4$ & 2.90 & 0.00 & 15.72 \\
\hline 7 & Small & 111 & 50 & $6.77 \pm 0.09$ & $175.4 \pm 14.2$ & 3.42 & 3.50 & 11.54 \\
\hline 7 & Medium & 112 & 50 & $8.01 \pm 0.06$ & $188.5 \pm 15.3$ & 3.04 & 0.00 & 14.76 \\
\hline 7 & Large & 127 & 50 & $8.63 \pm 0.05$ & $194.9 \pm 13.4$ & 2.80 & 4.76 & 15.78 \\
\hline 7 & Jumbo & 124 & 50 & $9.09 \pm 0.14$ & $196.6 \pm 12.5$ & 3.20 & 1.23 & 14.45 \\
\hline \multicolumn{9}{|l|}{ Main effects } \\
\hline 1 & & 495 & 200 & $8.15 \pm 0.08$ & $188.8 \pm 1.72$ & 2.89 & 4.48 & 14.86 \\
\hline 3 & & 510 & 200 & $8.20 \pm 0.09$ & $186.2 \pm 1.63$ & 2.92 & 4.91 & 14.44 \\
\hline 5 & & 483 & 200 & $8.20 \pm 0.08$ & $184.3 \pm 1.73$ & 3.08 & 3.45 & 13.77 \\
\hline 7 & & 474 & 200 & $8.12 \pm 0.09$ & $188.9 \pm 1.90$ & 3.11 & 2.37 & 14.12 \\
\hline Significance & & & & n.s & n.s & n.s & n.s & \\
\hline & Small & 458 & 200 & $6.81 \pm 0.05^{\mathrm{d}}$ & $180.7 \pm 1.40^{\mathrm{b}}$ & 3.12 & $7.43^{\mathrm{a}}$ & 12.75 \\
\hline & Medium & 495 & 200 & $7.92 \pm 0.03^{\mathrm{c}}$ & $183.3 \pm 1.93^{\mathrm{b}}$ & 3.01 & $2.65^{b}$ & 14.12 \\
\hline & Large & 496 & 200 & $8.56 \pm 0.04^{b}$ & $191.3 \pm 1.57^{\mathrm{a}}$ & 2.86 & $3.95^{\mathrm{b}}$ & 15.28 \\
\hline & Jumbo & 513 & 200 & $9.39 \pm 0.06^{\mathrm{a}}$ & $192.8 \pm 1.82^{\mathrm{a}}$ & 3.01 & $1.17^{\mathrm{b}}$ & 15.07 \\
\hline & Significance & & & $*$ & $* *$ & n.s & $*$ & \\
\hline
\end{tabular}

${ }^{\S}$ Small: <10.51 g; medium: 10.51-11.50 g; large: 11.51-12.50 g; jumbo: >12.51 g.

FCR - Feed conversion ratio

European Efficiency Factor (EEF): g gained/day X \% survival rate / conversion: 10

a-d. Within columns, within effects, values with different superscripts differ significantly at $\mathrm{P}<0.05(*)$ and $\mathrm{P}<0.01(* *)$

The main and interactive effects of hatching egg weight and length of storage on hatching time, apparent fertility, and hatchability of total and fertile eggs are shown in Table 2. The hatching time of chicks was significantly influenced by length of storage period and hatching egg weight $(\mathrm{P}<0.05)$. Observations started at $396 \mathrm{~h}$, at which time about 47.6, 13.8, 0.27, and $0 \%$ of chicks from the eggs stored for 1, 3, 5, and 7 days or $16.93,14.43,17.99$, and $13.71 \%$ of chicks in the small, medium, large and jumbo eggs respectively were already hatched. At the last control point (at $408 \mathrm{~h}$ of incubation) the hatching time of chicks hatched from small and jumbo eggs or stored for seven days was found to be longer than that of the others. This finding is concurrent with the findings of Nester \& Nable (2000), Smith (2000) and Inal (2001). Hatchability of fertile and total eggs increased $(\mathrm{P}<0.05)$ with an increase in egg weight but was not significantly affected by the length of egg storage period. The relatively low hatchability of small eggs can be explained by insufficient essential nutrients which might result in increased chick mortality. Apparent fertility was 89.5, 
$92.9,89.3$ and $86.7 \%$, in eggs stored for $1,3,5$, and 7 days, respectively, or $86.5,90.0,90.1$ and $92.1 \%$ in the small, medium, large and jumbo eggs, respectively. Although long storage time and hatching egg weight do not affect true fertility, the present study and the work of Elibol et al. (2002) suggested that long egg storage, except for one day prior to incubation, decreased $(\mathrm{P}<0.05)$ apparent fertility. In this study, there was no hatching egg weight $\mathrm{x}$ length of storage period interactions for the apparent fertility, or hatchability of total and fertile eggs.

The main and interactive effects of egg weight and length of storage period on growth performance of progeny are presented in Table 3. Body weight at hatch and $42 \mathrm{~d}$ of age was not affected by length of storage period. However, hatching egg weight did affect these parameters $(\mathrm{P}<0.05)$. Chicks hatched from eggs stored 1, 3, 5, and $7 \mathrm{~d}$ had similar initial and final weights. These results are in contrast to the findings of Sachdev et al. (1988) and Reis et al. (1997) who reported that the body weight of quail hatched from eggs stored for a short period was higher that when stored for longer periods. Initial chick weights were affected by hatching egg weight, with superiority of chicks from jumbo eggs, compared to those from small, medium and large eggs. Small eggs produced smaller offspring with smaller body weight at $42 \mathrm{~d}$ of age compared to those from the larger eggs. This result corroborates the findings of Among et al. (1984) and Farooq et al. (2001), and indicates that hatching egg weight, chick weight and chick growth are interrelated. In this study there were no significant differences in feed conversion ratio between the main groups. The mortality of quail was affected $(\mathrm{P}<0.05)$ by hatching egg weight. The survival rate of quails hatched from small eggs was found to be lower than in those from larger eggs. There was no hatching egg weight $x$ length of egg storage period interactions for body weight at hatch and $42 \mathrm{~d}$ of age, feed conversion ratio, and mortality rate. According to the European Efficiency Factor, which is the best indicator of bird performance, the growth performance of quails hatched from eggs stored for 1 and 3 days or large and jumbo eggs was found to be superior.

\section{Conclusions}

This study showed that the hatchability and growth performance of progeny were affected by length of storage period and hatching egg weight of quail. The hatchability and growth performance decreased with increasing length of storage and decreasing hatching egg weight. Eggs stored for no longer than 3 days and heavier than $11.5 \mathrm{~g}$ were found to be the most suitable for the optimum hatchability and subsequent growth performance.

\section{Acknowledgments}

This work was supported by funding from the Turkish Republic Prime Ministry State Planning Organization.

\section{References}

Among, T.K., Sharma, P.K., Bora, N.N. \& Baruah, K.K., 1984. Effect of egg weight and pre-incubation storage period on fertility and hatchability of WLH eggs. Ind. J. Poult. Sci. 19, 108-111.

AOAC, 1990. Official methods of analyses. (15th ed.). Association of Official Analytical Chemists, Inc. Arlington, Virginia, USA.

Ayorinde, K.L., Atteh, J.O. \& Joseph, K., 1994. Pre-and post hatch growth of Nigerian indigenous guinea fowl as influenced by egg size and hatch weight. Nigerian J. Anim. Prod. 21, 49-55.

Danczak, A. \& Majeska, D., 1999. Emu (Dromaius novaehdlandiae) hatch success and controls on hatchlings survival. Adv. Agric. Sci. 6, 25-30.

Dawes, C.M., 1975. Acid-base relationships within the avian egg. Biology Rev. 50, 351-376.

Deeming, D.C., 2000. Storage of hatching eggs. Poult. Int. 11, 44-48.

Elibol, O., Peak, S.D. \& Brake, J., 2002. Effect of flock age, length of egg storage, and frequency of turning during storage on hatchability of broiler hatching eggs. Poult. Sci. 81, 945-950.

Farooq, M., Aneela, K., Durrani, F.R., Muqarrab, A.K., Chand, N. \& Khurshid, A., 2001. Egg and shell weight, hatching and production performance of Japanese broiler quail. Sarhad J. Agric. 17, 289293.

Heier, B.T. \& Jarp, J., 2001. An epidemiological study of the hatchability in broiler breeder flocks. Poult. Sci. 80, 1132-1138.

Inal, S., 2001. Bildircin Yetistirme Bilgisi Ders Notları (In Turkish), S.U.Vet.Fac., Konya-Turkey. pp. 2-3. 
Kirk, S.S., Emmans, G.C., Mc Donald, E. \& Arnot, E., 1980. Factors affecting the hatchability of eggs from broiler breeders. Br. Poult. Sci. 21, 37-53.

McLoughlin, L. \& Gous, R.M., 1999. The effect of egg size on pre-post natal growth of broiler chickens. World Poultry-Elsevier. 15, 34-37.

Nahm, K.H., 2001. Effects of storage length and weight loss during incubation on the hatchability of ostrich eggs Struthio camelus. Poult. Sci. 80, 1667-1670.

Nester, K.E. \& Nable D.O., 2000. Influence of adult body weight and egg weight on hatchability time in selected and randombred control lines in turkey. Bull. Ohio State Univ. Res. and Rev. Poult. and Swine Special circ. pp. 164-99.

Nilipour, A.H.,1998. Numbers for successful poultry production. World Poultry-Elsevier. 14, 26-28.

NRC, 1994. Nutrient requirements of poultry (9th rev. ed.). National Academy Press, Washington DC.

Reis, L.H., Gama, L.T. \& Sacres, M.C., 1997. Effects of short storage conditions and broiler age on hatchability, hatching time and chick weight. Poult. Sci. 76, 1459-66.

Sachdev, A.K., Ahuja, S.D, Thomas, P.C. \& Agrawal, S.K., 1988. Effect of egg weight and storage periods of hatching eggs on growth of chicks in Japanese quail. Indian J. Poult. Sci. 23, 14-17.

Smith, T.W., 2000. Care and incubation of hatching eggs. Mississippi State Univ. Extension service. www.misstate.edu/dept/poultry/hatch.

Snedecor, G.W. \& Cochran, W.G.. 1989. Statistical Methods. (8th ed.). The Iowa State University Press, Ames, IA, USA.

SPSS $^{\circledR} 10.00$ Computer Software (1999) SPSS Inc, Headquarters, 233 s., Wacker Drive, Chicago, Illinois 60606, USA. 